Jurnal Basicedu Volume 4 Nomor 2 April 2020 Hal.268-279

JURNAL BASICEDU

Research \& Learning in Elementary Education

https://jbasic.org/index.php/basicedu

\title{
INTEGRASI PENGUATAN PENDIDIKAN KARAKTER (PPK) ERA 4.0 PADA PEMBELAJARAN BERBASIS TEMATIK INTEGRATIF DI SEKOLAH DASAR
}

\author{
Mitrakasih La Ode Onde ${ }^{1}$, Hijrawatil Aswat ${ }^{2}$, Fitriani B ${ }^{3}$, Eka Rosmitha Sari ${ }^{3}$ \\ Universitas Muhammadiyah Buton, Sulawesi Utara, Indonesia ${ }^{1,2,3}$ \\ Email: Mitrakasih_Laodeonde@yahoo.co.id ${ }^{1}$, Hijrawati_aswat@ yahoo.co.id ${ }^{2}$
}

\begin{abstract}
Abstrak
Penguatan Pendidikan karakter menjadi perhatian utama di era revolusi industry, dimana dunia anak mulai dipengaruhi oleh tekhnologi yang juga membawa dampak negatif bagi anak jika control guru dan orang tua lepas kendali. Penguatan Pendidikan karakter adalah Gerakan Pendidikan di sekolah untuk memperkuat karakter siswa melalui harmonisasi olah hati (etik), olah rasa (estetik), olah pikir (literasi), dan olah raga (kinestetik). Dimana penguatan Pendidikan karakter ini dilakukan secara terintegrasi kedalam semua mata pelajaran yang disajikan berdasarkan tema dengan menghadirkan nilai-nilai karakter sesuai dengan materi pelajaran yang dipelajari mulai dari kegiatan awal hingga kegiatan akhir pembelajaran. Pada tahap perencanaan dengan mengacu pada perangkat pembelajaran tertuang secara jelas nilai-nilai karakter yang termuat pada KI, KD, dan tahapan pelaksanaan kegiatan. Begitupun pada saat pelaksanaan kegiatan pembelajaran pada setiap tahapan sudah memunculkan penguatan Pendidikan karakter, meskipun tidak memunculkannya secara keseluruhan namun sudah mewakili beberapa nilai karakter yang diharapkan. Evaluasi penguatan pendidikan karakter dilakukan dengan melihat karakter spiritual siswa dan karakter sosial siswa melalui lembar observasi saat proses pengamatan secara langsung di kelas, catatan penting lainnya, dan protofolio.
\end{abstract}

Kata Kunci: Penguatan Pendidikan Karakter, Pembelajaran Tematik.

\begin{abstract}
Strengthening Character education is a major concern in the era of the industrial revolution, where the world of children is beginning to be influenced by technology which also has a negative impact on children if teacher control and parents are out of control. Strengthening character education is the Education Movement in schools to strengthen the character of students through the harmonization of though the heart (ethics), if the taste (aesthetic), though the mind (literacy), and sports (kinesthetic). Where the strengthening of character education is carried out integrated into all subjects presented based on the theme by presenting the character values in accordance with the subject matter being studied starting from the initial activity to the final activity of learning. At the planning stage with reference to the learning tools clearly outlined the character values contained in KI, KD, and the stages of the implementation of activities. Likewise, at the time of the implementation of learning activities at each stage the character education reinforcement has emerged, although it does not bring it up as a whole but already represents some expected character values. Evaluation of the strengthening of character education is done by looking at the spiritual character of students and social characteristics of students through the observation sheet during the process of direct observation in class, other important notes, and portfolio.
\end{abstract}

Keywords:Strengthening character education, Thematic learning

@Jurnal Basicedu 2020

$\triangle$ Corresponding author :

Address :-

Email :-

ISSN 2580-3735 (Media Cetak)

Phone :- 
269 Integrasi penguatan pendidikan karakter (PPK) Era 4.0 pada pembelajaran berbasis tematik integratif di sekolah dasar-Mitrakasih La Ode Onde, Hijrawatil Aswat, Fitriani B, Eka Rosmitha Sari

\section{PENDAHULUAN}

Pendidikan merupakan sesuatu hal yang sangat penting bagi kehidupan manusia. Pendidikan berusaha mengembangakan potensi individu agar mampu berdiri sendiri. Untuk itu, individu perlu diberi berbagai kemampuan dalam pengembangan beberapa hal seperti: konsep, prinsip, kreatifitas, tanggung jawab, dan keterampilan. Dengan kata lain perlu mengalami perkembangan dalam aspek kognitif, efektif, dan psikomotorik. Menurut Nanang Fattah (1996:5) mengemukakan fungsi pendidikan adalah membimbing anak kearah suatu tujuan yang bernilai tinggi. Pendidikan yang baik adalah usaha yang behasil membawa semua anak didik kepada tujuan pendidikan. Namun demikian, dunia pendidikan kita saat ini tengah mengalami krisis yang cukup serius. Krisis ini tidak hanya disebabkan oleh anggaran pemerintah yang sangat rendah untuk membiayai kebutuhan vital dunia pendidikan kita, tetapi juga mengalami krisis moral terhadap generasi penerus bangsa.

Guru merupakan ujung tombak pendidikan sebagaimana kita ketahui kualitas proses belajar mengajar sangat mempengaruhi kualitas pendidikan. Kegiatan belajar mengajar sangat ditentukan oleh kerjasama antara guru dan murid. Interaksi yang terjadi antara murid dengan guru memungkinkan murid dapat menyerap materi pelajaran dengan maksimal. Yang menjadi harapan semua guru adalah bagaimana murid dapat menerima pelajaran yang diberikan oleh guru terutama pendidikan karakter yang dapat diperoleh siswa melalui pembiasaan dan pemberian contoh secara langsung oleh guru.

Seiring $\begin{aligned} & \text { berjalannya } \\ & \text { tekhnologi, }\end{aligned}$
perkembangan
kurikulum sekolah dasar ikut update dan terus

mengalami perubahan demi tercapainya tujuan pendidikan yang diharapkan. Siswa tidak hanya dituntut pandai dalam segi ilmu pengetahuan tetapi juga memiliki akhlak atau moral dan etika yang baik yang mencerminka sikap kemanusiaan kita yang bermartabat.

Hadirnya tehnologi ditengah masyarakat, memberikan tantangan baru bagi orang tua terutama guru. Pengaruh-pengaruh negatif dari media televisi maupun media sosial yang banyak mempertontonkan kekerasan juga pelecehan yang tak layak dilihat oleh anak usia sekolah dasar merupakan awal rusaknya mental anak. Akhirakhir ini perilaku bulying, kekerasan dan pelecehan seksual marak terjadi bahkan pelakunya adalah anak dibawah umur. Tentu ini sangat menyayat hati, tak disangka kenapa bisa anak usia sekolah dasar sudah pandai menjadi pelaku kekerasan bahkan berpotensi seksual. Anak-anak banyak belajar dan mencontoh melalui media sosial yang mempertontonkan perilaku menyimpang dan kurangnya kontrol dari orang tua ketika memanjakan anak dengan memberikannya keleluasaan dalam mengakses gadgetnya.

Anak milenial saat ini sudah mengalami pergeseran moral dari anak zaman 90an kebawah, dimana guru merupakan orang tua kedua bagi siswa yang sangat disegani dan dihargai, namun saat sekarang ini banyak anak yang justru mempertontonkan perilakunya ketika menghina dan melawan gurunya melalui lisannya maupun secara fisik. Menelisik lebih jauh tentu yang memiliki tugas ini adalah guru yang berkordinasi dengan orang tua siswa. Pendidikan karakter awal diterima oleh anak adalah yaitu dari lingkungan keluarganya yang kemudian dikembangkannya di lingkungan sekolahnya. 
268 Integrasi penguatan pendidikan karakter (PPK) Era 4.0 pada pembelajaran berbasis tematik integratif di sekolah dasar-Mitrakasih La Ode Onde, Hijrawatil Aswat, Fitriani B, Eka Rosmitha Sari

Berdasarkan hasil penelitian sebelumnya oleh "Tentang penerapan pendidikan karakter dalam pembelajaran tematik di sekolah dasar menyimpulkan bahwa mulai dari perencanaan pendidikan karakter dalam pembelajaran tematik, pelaksanaan pendidikan karakter dalam proses pembelajaran, hingga evaluasi pendidikan karakter sudah tertuang dalam pembelajaran tematik meskipun secara keterlaksanaan masih sekitar 90\%" (Maharani 2016) . Sejalan dengan hasil penelitian yang dilakukan oleh Agestia Dewi (2017) "tentang implementasi nilai-nilai pendidikan karakter dalam pembelajaran tematik integratif pada kelas rendah, diperoleh hasil bahwa pada tahap perencanaan yang tertuang pada RPP telah memenuhi syarat tematik dan pada pelaksanaan pembelajaran pada setiap sup tema dilaksanakan dengan memasukkan pendidikan karanter didalamnya".

Guru tidak hanya bertugas menuntaskan siswanya dalam segi pengetahuannya tetapi juga mendidik anak dalam menanamkan nilai-nilai moral dalam berbuat dan bertutur sapa, karena usia sekolah dasar merupakan usia emas dimana sebagai permulaan membiasakan hal-hal yang baik. Dari beberapa ulasan diatas, peneliti bermaksud untuk melakukan penelitian dengan judul Integrasi Penguatan Pendidikan Karakter Pada Pembelajaran Berbasis Tema di Sekolah Dasar.

Pendidikan karakter merupakan upaya awal murid untuk membentuk dan menciptakan karakter pribadinya yang menjadi dasar dalam berbuat agar menjadi pribadi yang berguna untuk dirinya dan sekitarnya. Pendidikan karakter juga harus dibangun sejak dini guna menyempurnakan kehidupan selanjutnya yang lebih maju dan belajar membiasakan perilaku-perilaku yang baik.Tujuan pendidikan karakter sendiri adalah membentuk bangsa di mana masyarakatnya sangat erat dan berakhlak. Pentingnya pendidikan karakter memang harus di tanamkan sejak dini agar berkarakter pada diri anak karena jika pendidikan karakter itu kurang maka akan terjadi perilaku menyimpang di masyarakat seperti pergaulan bebas, kekerasan, kejahatan, dan perilaku yang merugikan orang lain.

"bahwasanya Karakter adalah ciri atau karakteristik atau gaya atau sifat khas dari diri seseorang yang bersumber dari bentukanbentukan yang diterima dari lingkungan, misalnya keluarga pada masa kecil, dan juga bawaan seseorang sejak lahir (Sjarkawi, Novrinda, and Bahar 2018) . Kertajaya (2010) mengemukakan bahwa Karakter adalah ciri khas yang dimiliki oleh suatu objek atau individu. Karakteristik yang asli dan berakar pada kepribadian atau individu benda, serta "mesin" yang mendorong bagaimana bertindak, berperilaku, katakanlah, dan menanggapi sesuatu. "pendidikan karakter memfokuskan menggali keutamaan manusia sehingga menjadi manusia yang sesungguhnya" (Koesoema 2007).Yakni dengan mengaktualisasikan nilai-nilai keutamaan seperti keuletan, tanggung jawab, kemurahan hati, dan lain-lain. Pendidikan karakter merupakan upaya yang terencana untuk menjadikan peserta didik mengenal, peduli dan menginternalisasi nilai-nilai sehingga peserta didik berperilaku sebagai insan kamil (Hudiyono, 2012:24).

"pengertian Pendidikan karakter sebagai suatu sistem penanaman nilai-nilai karakter kepada peserta didik yang meliputi komponen pengetahuan, kesadaran atau kemauan, dan tindakan untuk melaksanakan nilai-nilai tersebut, baik terhadap Tuhan Yang Maha Esa, diri sendiri, sesama, lingkungan, maupun kebangsaan 
269 Integrasi penguatan pendidikan karakter (PPK) Era 4.0 pada pembelajaran berbasis tematik integratif di sekolah dasar-Mitrakasih La Ode Onde, Hijrawatil Aswat, Fitriani B, Eka Rosmitha Sari

sehingga menjadi manusia insan kamil (Prasetyo and Marzuki 2016).

Berdasarkan penjelasan di atas, maka dapat diambil kesimpulan bahwa dalam mewujudkan pendidikan yang berkarakter adalah dengan mampu menanamkan nilai-nilai karakter kepada peserta didik sebagai fondasi agar terbentuknya silabus organisme generasi yang berkualitas, peka, dan peduli antar sesamanya. Sehingga nantinya bisa menjadi manusia insan kamil yang mandiri memiliki prinsip suatu kebenaran yang dapat dipertanggung jawabkan. Karakter yang diharapkan adalah agar generasi penerus bangsa ini memiliki prinsip hidup, berakhlak mulia, sopan santun baik dalam bertutur maupun dalam berpakaian, berhati baik, lembut, dan saling menghargai antar satu sama lain. Tujuan pendidika karakter menurut Salahudin (2013:109-110) antara lain: (1) menanamkan jiwa kepemimpinan dan tanggung jawab; mengembangkan siswa agar menjadi manusia yang mandiri, kreatif, dan berwawasan kebangsaan; dan (3) mengembangkan lingkungan kehidupan sekolah sebagai lingkungan belajar yang aman, jujur, dan penuh kreativitas.

Era revolusi industri 4.0 ini sangat berbeda dengan era sebelumnya, karena di era 4.0 ini sangat bergantung dengan internet. Semua proses kehidupan berkaitan dengan internet bahkan banyak beberapa aktivitas manusia yang digantikan oleh kehadiran internet. Bahkan dunia pendidikan pun bergantung dengan internet.

Revolusi industri adalah perubahan besar dan radikal terhadap bagaimana cara manusia memproduksi melalui jaringan internet yang menjadi penyatu dari berbagai negara, kalangan, bahkan masyarakat sekitar. Revolusi industri ini mulai dikenalkan pada tahun 2011 di acara Hamnover Trade Fairoleh ahli-ahli di berbagai bidang asal Jerman. Istilah revolusi industri 4.0 mulai dikenalkan pada tahun 2015 oleh Angella Markel di acara World Economic Forum (WEF). Tantangan terbesar bagi manusia agar tidak diberdayakan oleh tekhnologi namun memberdayakan tekhnologi itu sendiri. Era revolusi industri 4.0 ini diharapkan dapat menyejahterakan manusia bukan merobotkan manusia namun memberikan banyak peluang sekaligus tantangan yang berbeda dari masa-masa sebelumnya. Beberapa ilmuwan mengatakan bahwa dampak baik dari teknologi adalah mendukung dan meningkatkan kehidupan manusia, kemudian ilmuwan juga memperingatkan dampak buruk dari teknologi adalah ia mengasingkan dan menghilangkan. Di era revolusi industri 4.0 ini kita telah membongkar tradisi dan meninggalkan defisiensi. Masyarakat mudah tergoda dengan janji teknologi dan kehadirannya justru menggeser beberapa budaya yang ada di negara kita, salah satu contoh ketika berkumpul bercengkrama bersama disuatu tempat, tentu bukan pemandangan biasa lagi ketika masingmasing justru sibuk menatap layar gadget masingmasing sehingga kualitas kebersamaan sedikit tergerus.

Adanya era ini, tentu sangat berpengaruh pada pendidikan karakter generasi millenial. Bagaimana tidak, saat ini saja kita banyak menjumpai anak SMA bahkan SD telah menggunakan gadget. Ini termasuk dampak adanya revolusi industri 4.0. Belum lagi jika mereka menyalah gunakan fungsi gadget itu, seperti menonton hal-hal yang tidak sewajarnya (pornografi). Dari sini sudah terlihat bahwa era revolusi 4.0 sangat berpengaruh pada pendidikan karakter, terutama pada remaja hingga anak-anak. 
270 Integrasi penguatan pendidikan karakter (PPK) Era 4.0 pada pembelajaran berbasis tematik integratif di sekolah dasar-Mitrakasih La Ode Onde, Hijrawatil Aswat, Fitriani B, Eka Rosmitha Sari

Pembaharuan penguatan pendidikan karakter merupakan kebijakan pendidikan yang tujuan utamanya adalah untuk mengimplementasikan Nawacita Presiden Joko Widodo dan Jusuf Kalla dalam sistem pendidikan nasional. Kebijakan PPK ini terintegrasi dalam Gerakan Nasional Revolusi Mental (GNRM) yaitu perubahan cara berpikir, bersikap, dan bertindak menjadi lebih baik. Nilai-nilai utama PPK adalah religius, nasionalis, mandiri, gotong royong, integritas. Nilai-nilai ini ingin ditanamkan dan dipraktikkan melalui sistem pendidikan nasional agar diketahui, dipahami, dan diterapkan di seluruh sendi kehidupan di sekolah dan di masyarakat. Posisi pendidikan karakter di era revolusi industri 4.0 ini sangat penting karena manusia diharapkan untuk mempunyai karakter yang bijak dalam menggunakan teknologi dengan baik. PPK lahir karena kesadaran akan tantangan ke depan yang semakin kompleks, persaingan tekhnologi akan memajukan kehidupan manusia namun menghapus jejak tugas dan sebagian profesi manusia. Hal ini menuntut lembaga pendidikan untuk mempersiapkan peserta didik secara keilmuan dan kepribadian, berupa individuindividu yang kokoh dalam nilai-nilai moral, spiritual dan keilmuan. Memahami latar belakang, urgensi, dan konsep dasar PPK menjadi sangat penting bagi kepala sekolah agar dapat menerapkannya sesuai dengan konteks pendidikan di daerah masing-masing.

Tujuan pengembangan pendidikan karakter ialah untuk membangun dan membekali peserta didik sebagai generasi emas yang berakal dan berakhlak guna mengahdapi dinamika perubahan dimasa depan, meletakkan pendidikan karakter sebagai jiwa utama sesuai dengan keberagaman budaya, memperkuat potensi dan kompetensi ekosistem pendidikan.
Penguatan pendidikan karakter (PPK) dalam buku panduan Kementrian Pendidikan dan Kebudayaan Republik Indonesia mengemukakan bahwa penguatan pendidikan karakter adalah gerakan pendidikan di sekolah untuk memperkuat karakter siswa melalui harmonisasi olah hati (etik), olah rasa (estetis), olah pikir (literasi), dan olah raga (kinestetik) dengan dukungan pelibatan publik dan kerja sama antar sekolah, keluarga dan masyarakat. Olah hati (etik) merupakan individu yang memiliki kerohanian mendalam, beriman dan bertaqwa, jujur, adil, amanah, taat aturan, disiplin, bertanggung jawab, berempati, berani, pantang menyerah, rela berkorban, berjiwa patriotik, sopan, rendah hati, ulet dan menyukai tantangan. Olah rasa (estetis) merupakan individu yang memiliki integritas moral, rasa berkesenian dan berkebudayaan seperti saling menghargai, gotong royong, kebersamaan, ramah, hormat, toleran, nasionalis, peduli, mementingkan kepentingan umum, cinta tanah air, saling berbagi, dinamis, tenggang rasa, mencintai produk dalam negeri, senang berkreasi, menciptakan inovasi-inovasi demi kemajuan bangsa, mempertahankan keutuhan bangsa, dan bangga terhadap negara sendiri. Olah pikir (literasi) ialah individu yang memiliki keunggulan akademis sebagai hasil pembelajar sepanjang hayat seperti cerdas, kritis, kreatif, inovatif, produktif, rasa ingin tahu, terus belajar, berorientasi Ipteks, dan reflektif. Olah raga (kinestetik) ialah individu yang sehat dan mampu berpartisipasi aktif sebagai warga negara seperti bersih, sehat, sportif, tangguh, handal, bugar, berdaya tahan, bersahabat, kooperatif, determinatif, kompetitif, ceria dan gigih.

Ada 5 Nilai utama karakter prioritas penguantan pendidikan karakter dalam Permendikbud No. 20 tahun 2018 pasal 2 diantaranya: 
271 Integrasi penguatan pendidikan karakter (PPK) Era 4.0 pada pembelajaran berbasis tematik integratif di sekolah dasar-Mitrakasih La Ode Onde, Hijrawatil Aswat, Fitriani B, Eka Rosmitha Sari

1. Religius

Mencerminkan keberimanan terhadap Tuhan Yang Maha Esa, toleransi, dan cinta lingkungan.

2. Nasionalis

Menempatkan kepentingan Bangsa dan Negara diatas kepentingan diri dan kelompoknya, cinta tanah air, semangat kebangsaan, mentaati aturan, rela berkorban, kesadaran akan hak dan kewajiban, berjiwa patriotik dan menghargai kebhinekaan.

3. Integritas

Upaya menjadikan dirinya sebagai orang yang selalu dapat dipercaya dalam perkataan, tindakan, dan pekerjaan, keteladanan, kesantunan, amanah, kerja keras, disiplin, percaya diri, bertanggung jawab, rendah hati, sopan santun, menjaga lisan, lemah lembut dalam bertutur sapa, menghargai antar sesama terutama yang dituakan dan cinta pada kebenaran.

4. Gotong royong

Mencerminkan tindakan menghargai semangat kerja sama dan bahu membahu menyelesaikan persoalan bersama, solidaritas, saling menolong, kebersamaan, saling berbagi, tenggang rasa dan kekeluargaan.

5. Mandiri

Tidak bergantung pada orang lain dan mempergunakan tenaga, pikiran, waktu untuk merealisasikan harapan, mimpi dan cita-cita, kerja keras, kreatif, disiplin, berani, tidak mudah patah semangat dan pembelajar.

Penguatan pendidikan karakter dimulai dari lingkungan keluarga dan diteruskan ke lingkungan sekolah, guru berperan menanamkan nilai-nilai penguatan pendidikan karakter melalui pemodelan atau memberikan contoh dari perilaku gurunya sendiri dan mengenalkan melalui pembiasaan dan penyajian materi yang dikaitkan dalam satu tema.
Penguatan karakter siswa dalam mempersiapkan daya saing siswa dengan kompetensi abad 21 yaitu berpikir kritis, kreatif, komunikatif dan kolaborasi. Pembelajaran ini merupakan model pembelajaran terpadu yang menggunakan tema sebagai pemersatu kegiatan pembelajaran yang memadukan beberapa mata pelajaran sekaligus dalam satu kali tatap muka melalui satu topik pembahasan yang sudah mencakup lebih dari satu pembelajaran didalamnya. Tujuannya memberikan pengalaman yang bermakna bagi peserta didik dan menyajikan pembelajaran yang tak dibatasi lintas materinya sehingga siswa memahami berbagai konsep yang mereka pelajari harus selalu melalui pengalaman langsung dan menghubungkannya dengan konsep lain yang telah dikuasainya. Hal ini sejalan dengan menurut Sukmadinata $(2004 ; 197)$ lebih memandang pembelajaran tematik sebagai suatu model pembelajaran dengan fokus pada bahan ajaran. Bahan ajaran disusun secara terpadu dan dirumuskan dalam bentuk tema pembelajaran. Tema yang dimaksud adalah pokok pikiran atau gagasan pokok yang menjadi inti pembicaraan. Menurut Ahmdai dan Amri (2014) karakteristik dari pembelajaran terpadu adalah berpusat pada siswa, memberikan pengalaman langsung pada siswa, pemisahan antar pelajaran tidak begitu jelas, penyajian konsep dari berbagai mata pelajaran dalam satu proses pembelajaran dan bersifat luwes.

Dalam kurikulum 2013 selain kognitif, pendidikan karakter seperti religius, nasionalis, mandiri, gotong royong, dan integritas harus tercapai pada setiap individu peserta didik di Sekolah Dasar. Maka dari itulah, peneliti bermaksud untuk meninjau bagaimana penguatan pendidikan karakter dalam pembelajaran berdasarkan penyajian pembelajaran tematik terintegrasi di Sekolah Dasar. 
272 Integrasi penguatan pendidikan karakter (PPK) Era 4.0 pada pembelajaran berbasis tematik integratif di sekolah dasar-Mitrakasih La Ode Onde, Hijrawatil Aswat, Fitriani B, Eka Rosmitha Sari

\section{METODE}

Musfiqon (2012:14) memberikan pengertian bahwa "metode penelitian merupakan langkah dan cara dalam mencari, merumuskan, menggali data, menganalisis, membahas dan menyimpulkan masalah dalam penelitian". Penelitian ini merupakan jenis penelitian deskriptif. Penelitian ini menggunakan pendekatan kualitatif deskriptif yang mendeskripsikan, gambaran atau lukisan yang dianalisis secara langsung di lapangan terhadap fenomena, faktafakta permasalahan. "metode penelitian kualitatif sering disebut metode naturalistik karena penelitiannya dilakukan pada kondisi yang alamiah (natural setting)" (Sugiyono 2012).

penelitian dilaksanakan di Sekolah Dasar yang tersebar di Kota Baubau Sulawesi Tenggara untuk melihat integrasi penguatan pendidikan karakter yang ada di sekolah melaui pembelajaran tematik yang dibawakan oleh guru kelas. Subjek penelitian melalui purposif sampling dengan menetukan lokasi sekolah yang dianggap strategis dan masuk dalam kategori sekolah unggulan yang ada di Kota Baubau yang tersebar di dua kecamatan yakni Kecamatan Betoambari dan Kecamatan Murhum sebanyak 17 Sekolah Dasar yang terdiri dari 8 SD di kecamatan Betoambari dan 9 SD di Kecamatan Murhum.

Teknik pengumpulan data penelitian melalui lembar observasi guru mencakup pelaksanaan pembelajaran tematik yang memberikan makna penguatan pendidikan karakter, lembar observasi siswa dengan melihat aktivitas dan respon siswa selama proses pembelajaran dan karakter siswa ketika berada didalam kelas dan di luar ruang kelas atau saat interaksi dengan teman-temannya di lingkungan sekolah. Wawancara dan angket yang untuk diisi oleh siswa kaitannya dengan pendidikan karakter.

Data hasil penelitian dianalisis melalui Analisis data kualitatif adalah upaya yang dilakukan dengan jalan bekerja dengan data, mengorganisasikan data, memilah-milahnya menjadi satuan yang dapat dikelola, mensintesiskannya, mencari dan menemukan pola, menemukan apa yang penting dan apa yang dipelajari dan memutuskan apa yang dapat diceritakan kepada orang lain.

\section{HASIL DAN PEMBAHASAN}

Penguatan Pendidikan Karakter terbentuk berdasarkan fenomena pergeseran nilai moral anak-anak yang cukup memprihatinkan, ada beberapa nilai moral yang mulai terkikis dikerus oleh pergantian zaman dan masuknya budayabudaya asing, tentu hal ini dampak dari Revolusi Industri 4.0. masuknya perdagangan bebas antar negara tentu tidak hanya menguntungkan bagi suatu negara namun dampak negatifnya ialah ketidak siapan generasi milenial ini dalam memilih dan memilah budaya yang layak diadopsi dan sesuai dengan budaya Indonesia. Masuknya era internet cukup memberikan banyak kemudahan dalam mengakses situs-situs yang tidak layak dipertontonkan dihadapan anak-anak, menyajikan berbagai jenis game online dalam bentuk kekerasan dan kejahatan sehingga hal ini akan terekam oleh alam bawa sadar anak dan bisa mencontohnya kapan saja ketika ada kesempatan, apalagi kurangnya pengawasan dari orang tua dan memberikan kepulang kepada anak dengan memberi kuasa untuk memiliki gadgetnya sendiri. Jangan membiarkan anak mencari sendiri dan mencontoh nilai-nilai keseharian budaya asing, namun bimbing dan arahkan anak kita sebagai pemula dalam membiasakan diri berbuat dan 
273 Integrasi penguatan pendidikan karakter (PPK) Era 4.0 pada pembelajaran berbasis tematik integratif di sekolah dasar-Mitrakasih La Ode Onde, Hijrawatil Aswat, Fitriani B, Eka Rosmitha Sari

bertindah sesuai dengan etika. Penguatan pendidikan karakter merupakan respon dari sejumlah kelemahan dalam pelaksanaan pendidikan akhlak dan budi pekerti yang biasa disajikan oleh mata pelajaran agama dan pendidikan kewarganegaraan, sehingga dilakukan inovasi dalam bentuk penguatan pendidikan karakter yang dilakukan secara terintegrasi kedalam semua mata pelajaran yang disajikan dalam bentuk tema, dimana setiap teman wajib mengaitkan pesan moral didalamnya disertai dengan contoh tindakan oleh gurunya sendiri. Anik Ghufron (Zubaedi, 2011 : 263-264) mengemukakan bahwa "pengintegrasian nilai-nilai karakter kedalam kegiatan pembelajaran berarti memadukan, memasukkan, dan menerapkan nilainilai yang diyakini baik dan benar dalam rangka membentuk, mengembangkan, dan membina tabiat atau kepribadian peserta didik sesuai jati diri bangsa tatkala kegiatan pembelajaran berlangsung". Berdasarkan hasil penelitian, berikut beberapa penggunaan pendekatan didalam pengintegrasian penguatan pendidikan karakter yaitu:

1. Pendekatan berbasis kelas

Pendekatan berbasis kelas ini merupakan pelaksanaan kegiatan pembelajaran melalui pembelajaran tematik dalam satu rencana pembelajaran dalam bentuk tema. Tugas guru tidak hanya mengajar melainkan juga mendidik siswanya menjadi anak yang cerdas, berakhlak mulia dan berbudi pekerti. Generasi sekolah dasar merupakan ujung tombak pembentukan karakter yang baik melalui pembiasaan hal-hal yang baik yang nantinya akan menjadi kebiasaan siswa dan tanpa diberitahu atau diingatkan, siswa sudah paham dan menyadari tindakan yang tepat yang boleh dilakukannya. Untuk itu pendidikan karakter tidak bisa dipisahkan oleh pendidikan pada umunya melainkan menjadi satu kesatuan dengan pembelaajaran umum. Pelaksanaan Pembelajaran berbasis tema mendekatkan siswa dengan pemahamannya berdasarkan pengalaman dan pengetahuannya di lingkungan sekitarnya sehingga memudahkan guru dalam menanamkan pendidikan karakter pada siswa dengan mengaitkan dengan pembelajaran yang sedang dipelajarinya.

a. Analisis dokumen silabus dan RPP yang digunakan oleh guru

Berdasarkan hasil pengamatan peneliti dan wawancara dengan guru kelas dapat disimpulkan bahwa secara keseluruhan sudah menunjukkan adanya pengintegrasian penguatan pendidikan karakter pada pemeblajaran tematik pada setiap sub-sub tema dan pembelajaran dari rumusan KI,KD, Model pembelajaran, dan lembar evaluasi, namun hanya menfokuskan pada sikap sosial dan spiritual saja.

b. Proses pelaksanaan pembelajaran berbasis tematik integratif

Pelaksanaan pembelajaran terbagi menjadi tiga tahap yaitu kegiatan awal, kegiatan inti, dan kegiatan akhir atau penutup. "kelas menjadi komunitas belajar yang saling menumbuhkan dan mengembangkan, baik secara akademis, moral, kepribadian dan kerohanian (Koesoema 2007). Kelas menjadi tempat interaksi pertama siswa di lingkungan sekolah untuk itu bnayak pendidikan karakter yang bisa ditanamkan pada siswa salah satunya karakter kebersamaan. selama proses pembelajaran nilai karakter muncul pada peserta didik baik dalam kegiatan rutin maupun kegiatan spontan. Meskipun semua 
274 Integrasi penguatan pendidikan karakter (PPK) Era 4.0 pada pembelajaran berbasis tematik integratif di sekolah dasar-Mitrakasih La Ode Onde, Hijrawatil Aswat, Fitriani B, Eka Rosmitha Sari

nilai karakter dari 4 aspek dasar karakter yaitu olah hati, olah, rasa, olah pikir dan olah raga tidak semuanya muncul namun sudah ada beberapa pesan moral yang disampaikan dan dilaksanakan langsung baik oleh guru maupun siswa.

c. Tahap evaluasi

Penilaian merupakan mencakup hasil akhir siswa dari keseluruhan proses yang telah dilaluinya untuk menjadi acuan guru melalui ketuntasan yang diperoleh siswa dengan mengukur pencapaian tujuantujuan pembelajaran yang telah ditetapkan. Penilaian sebagai bahan evaluasi keterlaksanaan kurikulum, strategi mengajar guru dan capaian siswa dari 3 ranah yakni ranah kognitif, afektif, dan psikomotorik. Tahap evaluasi dilakukan oleh guru terdiri dari evaluasi harian melalui LKM atau lembar kerja murid, lembar observasi siswa, portofolio dan catatan penting lainnya. Kedua evaluasi mingguan dengan melihat capaian proses dalam satu sub tema yang telah terlaksana. Ketiga evaluasi semester melalui tahap penilaian hasil akhir melalui tes mencakup keseluruhan materi selama satu semeter dan mengevaluasi secara keseluruhan aktivitas siswa melalui evaluasi harian, mingguan dan semster.

\section{Pendekatan Berbasis budaya sekolah}

Penguatan pendidikan karakter melalui budaya sekolah dengan mengutamakan karakter prioritas yaitu religius, nasionalis, mandiri, gotong royong, dan integritas. Nilai karakter ini dilakukan melalui pembiasaan nilai-nilai utama dalam keseharian siswa seperti:

a. Shalat duhah bersama sebelum memasuki ruang kelas b. Upacara bendera setiap hari senin dan harihari nasional

c. Sebelum memasuki lingkungan sekolah, siswa satu persatu mengucap salam dan menyalami guru-guru yang menyambut siswa di gerbang sekolah

d. Sebelum bel berbunyi penanda masuk kelas, siswa diarahkan untuk membersihkan dan memungut sampah yang terlihat dihalaman sekolah

e. Siswa baris berbaris didepan kelas dalam rangka pemeriksaan kuku, rambut, mulut dan kerapihan pakaian

f. Agenda jumat bersih yaitu setiap hari jumat diadakan kerja bati bersama baik di lingkungan sekolah maupun lingkungan kelas

g. Agenda sabtu sehat yaitu senam bersama seluruh warga sekolah di lapangan sekolah dengan iringan musik olahraga sehat selama kurang lebih 30 menit

h. Kegiatan kokurikuler yakni kegiatan untuk memperdalamdan menghayati materi pelajaran yang telah dipelajarai dalam kegiatan intrakurikuler, yaitu dengan pemberian tugas pada siswa untuk membuat karya dalam bentuk proyek yang dikerjakannya sendiri sehingga membiasakan siswa dalam belajar mandiri sekaligus mengasah bakat siswa.

i. Kegiatan ekstrakurikuler yakni kegiatan yang dilakukan diluar kegiatan jam pelajaran dan didampingi oleh guru lain yang telah ditunjuk dan kegiatan ini disesuaikan dengan minat dan bakat siswa, salah satu kgiatannya yaitu kegiatan pramuka yang mengajarkan sisi kebersamaan, tangguh, berjiwa pemimpin, cinta tanah air dan jiwa sosial, kegiatan ini hanya memperkenalkan dasar-dasar 
275 Integrasi penguatan pendidikan karakter (PPK) Era 4.0 pada pembelajaran berbasis tematik integratif di sekolah dasar-Mitrakasih La Ode Onde, Hijrawatil Aswat, Fitriani B, Eka Rosmitha Sari

kepramukaan. Selain dari itu kegiatan ekstrakurikuler yang sesuai dengan minat dan bakat siswa belum terlaksana dengan baik karena kurangnya fasilitas penunjang dan kondisi lingkungan sekolah yang kurang memadai untuk dilakukan latihan dan sebagainya.

j. Melakukan peninjauan keterlaksanaan tata tertib guru dan siswa

k. Melaksanakan tradisi perayaan hari-hari besar keagamaan maupun kenegaraan dan melaksanakan tradisi makan bersama dipenghujung semester sebagai bentuk kesyukuran dan mempererat tali kekeluargaan.

3. Pendekatan berbasis masyarakat

Masyarakaat yang dimaksud adalah komite sekolah yaitu orang tua siswa. Kokohnya pondasi pendidikan karakter tergantung dari lingkungan keluarga dan sekolah, untuk itu antara sekolah dan keluarga siswa harus bersinergi dalam membentuk penguatan pendidikan karakter sejak dini. Pihak sekolah mengundang orang tua siswa menghadiri rapat dalam rangka pelatihan penguatan pendidikan karakter dengan meperkenalkan cakupan pendidikan karakter, dan arahan-arahan untuk konsisten terhadap nilai karakter yang dilakukan di sekolah dan dilanjutkan ketika siswa berada di lingkungan keluarga maupun di lingkungan masyarakat sekitarnya. Sehingga ruang-ruang pengaruh negatif dari luar tidak mudah diserap oleh siswa melalui pendampingan orang tua.

\section{Perencanaan Penguatan Pendidikan}

Karakter dalam Pembelajaran Tematik Integratif di Sekolah Dasar. Tahap perencanaan ini seperti menyusun perangkat pembelajaran yang dilakukan guru sebelum tahun ajaran baru atau semster baru. Perangkat pembelajaran yang dimaksud mulai dari kalender pendidikan, program tahunan (prota), program semester (promes), silabus, dan RPP. Silabus dan RPP dikembangkan oleh guru disesuaikan dengan karakteristik siswa. Berdasarkan dokumen silabus dan RPP yang diperlihatkan oleh guru terlihat bahwa pengintegrasian penguatan pendidikan karakter dalam muatan materi pelajaran berbasis tema sudah terlihat dari rumusan $\mathrm{KI}, \mathrm{KD}$, tahapan pelaksanaan kegiatan pembajaran, dan lembar evaluasi yang digunakan. Namun tahapan kegiatan pada lembar RPP tidak terealisasi sesuai dengan yang dicantumkan di RPP, kenyataannya guru melaksanakan proses pembelajaran ceramah dan penugasan. Lembar evaluasi mencakup ranah kognitif, afektif dan psikomotorik dan untuk penilaian sikap terdiri dari sikap spiritual dan sikap sosial siswa yang masing-masing dijabarkan lagi dalam bagian-bagiannya. Tahap perencanaan guru tidak memasukkan list perencanaan pembuatan media sehingga pembelajaran terlaksana tanpa disertai contohcontoh kongkrit. Sehingga dari beberapa perencanaan yang sudah tertuang dalam RPP tidak dilaksanakan secara baik. Alasan mendasar dari hasil wawancara dengan pihak guru karena kurang menguasai model-model pembelajaran, kurangnya pendanaan pembuatan media pembelajaran dan waktu luang guru tersita untuk pembuatan atau pemenuhan administrasi kelas. Sejatinya perencanaan ini tidak hanya sekedar tulisan biasa melainkan acuan dalam melaksanakan proses belajar mengajar di kelas, namun ketika ini tidak terlaksana maka untuk siapa dan untuk apa RPP ini dibentuk. Perencanaan yang matang akan menghasilkan yang baik, apalagi ini berkaitan dengan karakter siswa, yang 
276 Integrasi penguatan pendidikan karakter (PPK) Era 4.0 pada pembelajaran berbasis tematik integratif di sekolah dasar-Mitrakasih La Ode Onde, Hijrawatil Aswat, Fitriani B, Eka Rosmitha Sari

sejatinya akan mencerminkan kepribadian siswa dan dibawanya hingga akhir hayatnya.

Pelaksanaan Penguatan Pendidikan Karakter dalam Pembelajaran Tematik Integratif di Sekolah Dasar. Dari perencanaan yang telah dibuat oleh guru , selanjutkan diimplementasikan dalam kegiatan belajar mengajar di kelas. Sasaran penelitian ini adalah bagaimana integrasi penguatan pendidikan karakter dalam pembelajaran berbasis tema. Kegiatan pembelajaran terbagi menjadi kegiatan awal, kegiatan inti, dan kegiatan akhir atau penutup. Guru mengintegrasikan nilai-nilai moral pada anak disetiap kegiatan pembelajaran dan juga dalam menyampaikan materi pelajaran diberikan contoh-contoh perilaku dan tutur sapa yang baik disesuaikan dengan materi pelajaran yang dipelajarinya. Walaupun nilai-nilai karakter itu tidak semua muncul namun sudah mewakili beberapa nilai karakter utama seperti gotong royong, integritas, nilai ketuhanan, dan nilai mandiri. Hal ini memang tidak memungkinkan memuncul secara bersamaan semua nilai karakter yang dikembangkan oleh kihajar dewantara namun sudah ada beberapa yang masuk dalam lingkup materi pelajaran, karena hal ini juga disesuaikan dengan tema yang dipelajari siswa saat itu, tentu untuk subsub tema lainnya akan menghadirkan nilai-nilai karakter lainnya.

a. Kegiatan awal pembelajaran

pada kegiatan awal yang berlangsung slama lebih dari 15 menit nilai karakter sudah muncul mulai dari nilai karakter religius, disiplin, kekeluargaan yang ditandai dengan saling mengisi dan berbagi apabila ada siswa yang tidak membawa alat tulisnya, mengecek jadwakl kebersihan kelas dan memastikan siswa yang diberi tugas telah melaksanakan tugasnya dengan baik, mengecek kembali kebersihan kelas dan karakter gemar membaca melalui membaca lima belas menit sebelum pelajaran dimulai. Selain dari itu guru juga membiasakan siswa menyanyikan lagu-lagu kebangsaan sebagai bentuk kecintaan terhadap negara kita, berdo'a sebelum pelajaran dimulai berdasarkan keyakinan masing-masing, dan kegiatan apersepsi diisi dengan bercerita singkat yang ada kaitannya dengan materi pelajaran dimana isi dari ceirta ini menyampaikan pesan moral yang baik.

b. Kegiatan inti pembelajaran

Pada kegiatan inti merupakan kegiatan yang mencakup pembahasan tuntas materi pelajaran dengan acuan langkah-langkah pelaksanaan pembelajaran yang tertuang dalam RPP, dari hasil observasi di kelas dan wawancara selama proses pembelajaran guru melaksanakan pembelajaran langsung dengan metode ceramah, menyampaikan materi pelajaran dan pemberian tugas, permainan, percobaan dan diskusi kelompok. Saat proses penyampaian materi guru melaksanakan proses tanya jawab untuk mengulik pengetahuan dan pengalaman siswa sesuai dengan materi pelajaran yang dibahas. Dari kegiatan inti dapat dismpulkan bahwa nilai karakter yang termuat dalam pembelajaran tematik contohnya pada kelas 4, tema 1 , sub tema 2 tentang indahnya kebersamaan. memunculkan nilai-nilai gotong royong, nilai keberagaman budaya indonesia, selalu bersyukur kepada Tuhan yang Maha Esa dari segala nikmat-Nya, hidup rukun, hidup bersih, kerja sama dengan semangat, ikut bagian dalam setiap kegiatan, tolong menolong, memperkenalkan permainan tradisional yang sangat erat dengan kebersamaan, dan nilai-nilai toleransi. Dari satu sub tema sudah 
277 Integrasi penguatan pendidikan karakter (PPK) Era 4.0 pada pembelajaran berbasis tematik integratif di sekolah dasar-Mitrakasih La Ode Onde, Hijrawatil Aswat, Fitriani B, Eka Rosmitha Sari

mengintegrasikan beberapa nilai-nilai karakter didalamnya. Begitupun untuk tema-tema yang lainnya. Secara keseluruhan praktik atau contoh nilai karakter itu sendiri diperoleh siswa dari gurunya sendiri sebagai modeling dan tempat siswa mencontoh. Untuk itu guru patutlah ditiru dan digugu baik dari segi berpakaian, bertutur sapa, berprilaku dan bersosial antar sesama guru dan guru dengan siswa. Disisi lain sumber belajar yang digunakan guru masih belum variatif, sehingga hanya berpatokan pada satu buku saja sebagai acuan sehingga contoh-contoh nilai karakter itu sendiri cukup dibatasi, selain dari itu keterbatasan model pembelajaran yang digunakan karena tidak menggunakan berbagai model pembelajaran yang variatif yang kental akan bentuk kelompok sehingga memberikan peluang kepada siswa untuk menguatkan nilai kerjasama, kebersamaan, dan nilai musyawarah dan saling menghargai pendapat antar kelompok.

\section{c. Kegiatan akhir atau penutup}

Kegiatan akhir siswa diajak untuk merangkum pembelajaran sehingga terbiasa dalam mengemukakan pendapatnya hasil dari pelajaran yang dipelajarinya, guru menyampaikan pesan-pesan moral, siswa diajak bernyanyi dengan nyanyian yang menyampaikan wejangan atau petuah yang baik atau tentang jasa-jasa guru, terutama nyanyian sentuhan boleh dan sentuhan tidak boleh, untuk memberikan edukasi dan pemahama kepada siswa agar membatasi orang lain menyentuh anggota tubuh yang terlarang, guna mengurangi tindak kekerasan dan pelecehan pada anak, siswa membaca do'a, disiplin dalam duduk dengan memberikan peluang kepada siswa yang duduk rapih untuk terlebih dahulu meninggalkan ruang kelasnya, bersalaman dengan ibu gurunya dan mengucapkan terimakasih dan salam kepada guru kelasnya.

1. Evaluasi Penguatan Pendidikan Karakter dalam Pembelajaran Tematik Integratif di Sekolah Dasar

Penerapan nilai karakter pada pembelajaran tematik tidak hanya dinilai dari segi kecerdasan siswa tapai bagaimana interaksi siswa selama proses pembelajaran berlangsung. Tahap mengumpulkan data evaluasi siswa terbagi menjadi tiga ranah yakni ranah kognitif yang dievaluasi melalui tes, penugasan dan portofolio. Kedua ranah afektif yakni sikap siswa yang dinilai melalui lembar observasi, caatatan penting dan hasil pengamatan langsung. Evaluasi sikap siswa terbagi menjadi 2 yaitu:

a. Sikap spiritual

Sikap spiritual yang tertuang dalam (KI-1) meliputi sikap peserta didik dalam ketaatan beribadah, pengucapan salam ketika bertemu guru, orang tua, orang yang lebih tua dan teman, sikap berdo'a sebelum dan setelah pelajaran, membaca basmalah dan duduk ketika memulai makan dan minum, toleransi dalam beribadah, bersyukur.

b. Sikap sosial

Penilaian sikap sosial tertuang dalam (KI-2) meliputi bersikap jujur, disiplin, tanggung jawab, santun, peduli, percaya diri, mandiri.

Penilaian sikap siswa dievaluasi melalui observasi yang dilakukan selama proses belajar mengajar berlangsung dengan membuat lembar observasi dan catatan penting ketika ada tindakan yang dilakukan siswa diluar dari yang telah dibuat dalam instrumen observasi, dan 
278 Integrasi penguatan pendidikan karakter (PPK) Era 4.0 pada pembelajaran berbasis tematik integratif di sekolah dasar-Mitrakasih La Ode Onde, Hijrawatil Aswat, Fitriani B, Eka Rosmitha Sari

portofolio. Dalam pelaksanaan pembelajaran, penilaian spiritual hanya sebagian yang terlaksana sehingga siswa masih membutuhkan bimbingan dan pembiasaan agar nilai-nilai karakter ini dibiasakannya. Penilaian sosial secara keseluruhan sudah terlaksana dengan baik ditandai dengan tanpa perintah guru, siswa membantu temannya yang kesusahan menyelesaikan tugas soal yang diberikan oleh guru dan ketika jam istrahat tiba terlihat beberapa siswa berbagi makanan ringan dengan temannya. Meskipun ada beberapa anak yang masih bersikap cuek dan hanya sibuk dengan aktivitasnya sendiri, namun hal ini menjadi PR bagi guru untuk terus membimbing siswanya dan terus memberikan contoh yang baik dan penerapan pembiasaan nilai-nilai karakter dalam keseharian siswa.

Dari segi lingkungan fisik kelas masih kurang memadai ditandai dengan pengaturan bangku yang kurang variatif dan tempelan media pembelajaran di dinding kelas yang sangat sunyi. Sebaiknya media-media pajangan ini dibuat disesuaikan dengan tema pembelajaran di kelas tersebut sehingga ketika pelajaran dimulai, media tersebut dapat dihadirkan ditengah-tengah siswa. Begitupun untuk potongan kata-kata motivasi sebaiknya dipajang agar menjadi pengingat dan prinsip untuk siswa dalam embangun motivasi dan nilai karakternya.

\section{SIMPULAN}

Berdasarkan hasil penelitian dapat disimpulkan bahwa perencanaan penguatan pendidikan karakter dalam pembelajaran tematik integratif sudah terintegrasi dalam muatan RPP pada KI-1 dan KI-2, KD, strategi pembelajaran dan evaluasi. Pelaksanaan pembelajaran tematik pada tahap kegiatan awal, kegiatan inti, dan kegiatan akhir atau penutup sudah muncul beberapa nilai karakter utama diantaranya nilai religius, nilai integritas, nilai gotong royong, nilai cinta tanah air, dan nilai kemandirian pada siswa. Evaluasi penguatan pendidikan karakter dilakukan dengan melihat karakter spiritual siswa dan karakter sosial siswa melalui lembar observasi saat proses pengamatan secara langsung di kelas, catatan penting lainnya, dan protofolio.

Saran dari peneliti berdasarkan hasil penelitian dan kesimpulan yaitu kepala sekolah sebaiknya melakukan monitoring kepada setiap guru pemegang kelas dalam pelaksaaan proses belajar mengajar agar guru betul-betul melaksanakan pembelajaran tematik ini dengan mengaitkan satu mata pelajaran dengan mata pelajaran yang lainnya sesuai ketentuan dengan cara yang tersamarkan agar mata pelajaran ini tidak terlihat terpenggal atau bukan dari satu kesatuan dari tema. Pihak sekolah terus mengadakan pembenahan dan melakukan pelatihan kepada guru dan orang tua siswa terkait penguatan pendidikan karakter.

\section{DAFTAR PUSTAKA}

Ahmadi,L.K. dan Amri, S. 2014. Pengembangan dan Model Pembelajaran Tematik Integratif. Jakarta:PT Prestasi Pustakarya.

Agestia Dewi Novita. 2017. "IMPLEMENTASI NILAI-NILAI PENDIDIKAN KARAKTER DALAM PEMBELAJARAN TEMATIK INTEGRATIF PADA KELAS RENDAH SD KARANG TENGAH 3" Jurnal Pendidikan.

Harmawan Kartajaya. 2010. Grow with Character : The Model Marketing. Jakarta : PT. Gramedia Pustaka Utama.

Koesoema, Doni. 2007. Jakarta: Grasindo Pendidikan Karakter: Strategi Mendidik Anak Di Zaman Global. 
279 Integrasi penguatan pendidikan karakter (PPK) Era 4.0 pada pembelajaran berbasis tematik integratif di sekolah dasar-Mitrakasih La Ode Onde, Hijrawatil Aswat, Fitriani B, Eka Rosmitha Sari

Kementrian Pendidikan dan Kebudayaan Republik Indonesia. 2017. Gerakan Penguatan Pendidikan Karakter (PPK).https:kemdigbud.go.id/15/08/19

Musfiqon. 2012. Metodologi Penelitian Pendidikan. Jakarta : Prestasi Pustaka

Maharani, Idhes Sara Andrieta. 2016. "PENGEMBANGAN MODUL TEMATIK CITA-CITAKU BAGI SISWA KELAS IV SEKOLAH DASAR." E-Jurnal Skripsi Program Studi Teknologi Pendidikan.

Permendikbud No. 20 Tahun 2018 Pasal 2 Tentang Lima Nilai Utama karakter yang dikembangkan sebagai prioritas gerakan PPK.

Prasetyo, Danang, and Marzuki Marzuki. 2016. "PEMBINAAN KARAKTER MELALUI KETELADANAN GURU PENDIDIKAN KEWARGANEGARAAN DI SEKOLAH ISLAM AL AZHAR YOGYAKARTA." Jurnal Pendidikan Karakter.

Sugiyono. 2012. "Metode Penelitian Kuantitatif, Kualitatif Dan R \& D.Bandung:Alfabeta." Metode Penelitian Kuantitatif, Kualitatif dan R \& D.Bandung:Alfabet

Sjarkawi, Gita, Herry Novrinda, and Armasastra Bahar. 2018. "PENGARUH TRADISI NASI

PAPAH TERHADAP RISIKO TERJADINYA EARLY CHILDHOOD CARIES DI DESA SENYIUR LOMBOK TIMUR.” B-Dent, Jurnal Kedokteran Gigi Universitas Baiturrahmah.

Salahudin, A. 2013. Pendidikan Karakter Berbasi Agama dan Budaya Bangsa. Bandung : Pustaka Setia

Sukmadinata \& Nana Syaodih. 2004. Pengembangan Kurikulum. Bandung : Rosdakarya.

Shudiyono. 2012. Membangun Karakter Siswa. Jakarta:Esensi, ErlanggaGrup

Zubaedi. 2011. Desain Pendidikan Karakter.Jakarta:Kencana Prenada 